\title{
Childhood cancer incidence by ethnic group in England, 2001-2007: a descriptive epidemiological study
}

\author{
Shameq Sayeed ${ }^{1}$, Isobel Barnes ${ }^{1}$ and Raghib Ali $^{1,2^{*}}$ (D)
}

\begin{abstract}
Background: After the first year of life, cancers are the commonest cause of death in children. Incidence rates vary between ethnic groups, and recent advances in data linkage allow for a more accurate estimation of these variations. Identifying such differences may help identify potential risk or protective factors for certain childhood cancers. This study thus aims to ascertain whether such differences do indeed exist using nationwide data across seven years, as have previously been described in adult cancers.

Methods: We obtained data for all cancer registrations for children (aged 0-14) in England from January 2001 to December 2007. Ethnicity (self-assigned) was established through record linkage to the Hospital Episodes Statistics database or cancer registry data. Cancers were classified morphologically according to the International Classification of Childhood Cancer into four groups - leukaemias; lymphomas; central nervous system; and other solid tumours. Age standardised incidence rates were estimated for each ethnic group, as well as incidence rate ratios comparing each individual ethnic group (Indian, Pakistani, Bangladeshi, Black African, Black Carribean, Chinese) to Whites, adjusting for sex, age and deprivation.

Results: The majority of children in the study are UK born. Black children ( $R R=1.18,99 \%$ Cl: 1.01-1.39), and amongst South Asians, Pakistani children ( $R R=1.19,99 \%$ Cl: 1.02-1.39) appear to have an increased risk of all cancers. There is an increased risk of leukaemia in South Asians ( $R R=1.31,99 \% \mathrm{Cl}: 1.08-1.58$ ), and of lymphoma in Black ( $R R=1.72,99 \% \mathrm{Cl}: 1.13-2.63)$ and South Asian children ( $R R=1.51,99 \% \mathrm{Cl}: 1.10-2.06)$. South Asians appear to have a decreased risk of CNS cancers ( $R R=0.71,99 \%$ Cl: $0.54-0.95)$.

Conclusions: In the tradition of past migrant studies, such descriptive studies within ethnic minority groups permit a better understanding of disease incidence within the population, but also allow for the generation of hypotheses to begin to understand why such differences might exist. Though a major cause of mortality in this age group, childhood cancer remains a relatively rare disease; however, the methods used here have permitted the first nationwide estimation of childhood cancer by individual ethnic group.
\end{abstract}

Keywords: Childhood cancer incidence, England, Ethnic minorities

\footnotetext{
* Correspondence: raghib.ali@ndm.ox.ac.uk

${ }^{1}$ Cancer Epidemiology Unit, University of Oxford, Richard Doll Building, Oxford OX3 7LF, UK

${ }^{2}$ Public Health Research Center, New York University Abu Dhabi, Abu Dhabi,

United Arab Emirates
} 


\section{Background}

In 2009, Cancer Research UK (CRUK) published Cancer Incidence and Survival By Major Ethnic Group for England 2002-2006 [1], linking incidence and mortality data from cancer registries with (self-assigned) ethnicity from the Hospital Episodes Statistics (HES) database. This methodology allowed a much more accurate estimation of outcomes by ethnic group and confirmed differences in incidence and survival in many of the different cancer types, with CRUK concluding that these differences needed 'investigating further and the analyses extended'.

We have since published a series of papers to do that by looking more closely at individual ethnic groups and their differences in cancer incidence. South Asians and Blacks are not homogenous groups, with the subgroups within these broad categorisations having differing religious, social and cultural practices. We thus analysed cancer incidence in gastrointestinal [2], haematological [3], thyroid [4], breast and gynaecological [5], urological [6] and CNS [7] malignancies nationwide, looking individually at the difference between British Indians, Pakistanis, Bangladeshis ('South Asians'), Black Africans, Black Carribeans ('Blacks') and Whites. These consistently show differences in incidence between the ethnic groups in many cancers; interestingly, they also suggest that these differences - between British Whites and ethnic minorities - can become less marked in some cancers over time [2], in keeping with previous studies in migrant populations [8] and suggesting possible environmental risk and protective factors where such patterns are observed over the space of a few generations.

Whilst some of these differences can be accounted for through known risk factors, there are many for which we do not currently have any good explanation. Thus, accurately confirming these ethnic differences (and related outcomes) through linked data, and using self-assigned ethnicity as the current most accurate measure of ethnicity $[9,10]$, allows not only for targeted public health spending and interventions, but is also a first step in attempting to identify potentially modifiable risk factors.

Beyond the first year of life, cancer is the commonest cause of death in childhood (ages 0-14) in England and Wales [11]. Whilst the CRUK report did not study this, here we consider for the first time the nationwide data for childhood cancer (2001-2007), using self-assigned ethnicity data and widening the analysis to include all of the above mentioned ethnic subgroups.

\section{Methods}

The methods used in this study were broadly the same as those described in our previous studies [2-7, 12].

\section{Data collection}

The National Cancer Intelligence Network (NCIN) provided data for all cancer registrations from January 2001 to December 2007 in residents of England aged 0 to 14 years old. For each registration, the following information was given: cancer site coded to the International Classification of Diseases, 10th Revision (ICD-10) [13]; morphology coded to the International Classification of Diseases of Oncology, 2nd and 3rd Revisions (ICD-O-2 and ICD-O-3) [14, 15]; deprivation assessed from the income domain of the Index of Multiple Deprivation 2007 (IMD 2007) [16]; age at diagnosis of cancer; sex and ethnicity. We used the mid-year population estimates produced by the Office of National Statistics (ONS) from 2001 to 2007, stratified by age, sex and ethnicity. Population data stratified by national quintiles of the income domain were provided by ONS based on the 2001 census and the same distributions applied to population data by age, sex and ethnicity for the 2001-2007 mid-year population estimates.

\section{Classification of ethnicity}

NCIN obtained the self-assigned ethnicity for each cancer registration by record linkage to the HES database. If a cancer registration could not be linked or if ethnicity was missing on the HES database, then ethnicity was assigned using the cancer registry data. Prior to April 2001, ethnicity was classified by HES and the cancer registries according to the codes used in the 1991 census. After April 2001, the codes were amended to those used in the 2001 census, although 1991 ethnicity codes were accepted until 2003. For the analyses presented in this paper, ethnicity was classified as White (White from the 1991 Census and White British from the 2001 Census), Indian, Pakistani, Bangladeshi (with the three groups combined to form the category of 'South Asian'), Black African, Black Caribbean (again both combined to form the category 'Black') and Chinese.

\section{Classification of cancers}

We used morphology to classify cancers according to the International Classification of Childhood Cancer (ICCC-3) [17]. To do this we converted ICD-O codes from the second to third edition as necessary. As in previous studies [18], we classified cancers into four groups corresponding to the diagnostic groups I, II, III and IVXII of the ICCC-3. These groups are respectively: leukaemias and myloproliferative and myelodysplastic diseases; lymphomas and reticuloendothelial neoplasms; central nervous system and intracranial and intraspinal neoplasms; and other solid tumours. 


\section{Statistical analyses}

We estimated age standardized rates (ASRs) of cancer per 100,000 person-years for all ethnic groups using direct standardization to the 1960 Segi world population [19], with age at diagnosis of cancer being classified into three categories: $0-4,5-9$, and $10-14$ years. We used Poisson regression to estimate incidence rate ratios (IRRs) comparing each ethnic group (and the two combined groups, South Asians and Blacks) to Whites adjusting for sex, age and deprivation.

When comparing South Asians and Blacks to Whites, we present results as IRRs and 99\% confidence intervals (CIs). When comparing the individual ethnic groups, results are presented as IRRs and 99\% floating confidence intervals (FCIs). FCIs were calculated using the method of floating absolute risks $[20,21]$ and enable valid comparisons between any two ethnic groups, even if neither one is the baseline. We calculated 99\% CIs because of multiple tests performed across ethnic groups. Tests of heterogeneity of IRRs between ethnicities, either overall or restricted to South Asians or Blacks, were performed using likelihood $x^{2}$ ratio tests.

We performed pre-specified subgroup analyses by sex. Tests of heterogeneity of IRRs between subgroups were performed for South Asians, Blacks and Chinese using a $\chi^{2}$ contrast test.

Because ethnicity information was not complete for all registered cancers, we performed a sensitivity analysis using multiple imputations of the missing ethnicity values based on age, sex, income and site of cancer.
We performed all analyses using Stata V.12 and R statistical software packages [22, 23].

\section{Graphical presentation of results}

Where results are presented in the form of plots, we represent IRRs for each ethnic group by squares and their corresponding $99 \%$ FCIs by straight lines. For the combined South Asian and Black groups, we show IRRs as open diamonds, whose horizontal extent indicates the 99\% CI. We placed dashed vertical lines at the value of the IRRs for South Asians and Blacks.

\section{Results}

Demographic information for children in England from the 2001 Census is presented in Table 1. The total childhood population in England was 9,277,814 of which the majority (84.2\%) were White.

There is a greater proportion of older children amongst Whites, Indians, Black Carribeans and Chinese, with the reverse being seen in Pakistanis, Bangladeshis and Black Africans. Levels of deprivation also differed with the majority of Pakistanis, Bangladeshis, and Blacks having low incomes and the remaining ethnic groups being mostly middle or high income.

The majority of children were UK born, though the proportion varies between different ethnic groups from 68\% in Black Africans to $93 \%$ in Black Carribeans and Indians.

Table 1 Comparison of demographics for children from major ethnic groups within the UK

\begin{tabular}{|c|c|c|c|c|c|c|c|c|c|c|c|c|c|c|c|c|}
\hline \multirow[t]{2}{*}{ Ethnic group } & \multicolumn{2}{|l|}{ White } & \multicolumn{2}{|l|}{ Indian } & \multicolumn{2}{|l|}{ Pakistani } & \multicolumn{2}{|c|}{ Bangladeshi } & \multicolumn{2}{|c|}{ Black African } & \multicolumn{2}{|c|}{$\begin{array}{l}\text { Black } \\
\text { Caribbean }\end{array}$} & \multicolumn{2}{|l|}{ Chinese } & \multicolumn{2}{|l|}{$\begin{array}{l}\text { Other } \\
\text { Ethnicity }\end{array}$} \\
\hline & $N$ & (\%) & $N$ & (\%) & $N$ & $(\%)$ & $N$ & $(\%)$ & $N$ & (\%) & $N$ & (\%) & $N$ & (\%) & $N$ & (\%) \\
\hline \multicolumn{17}{|c|}{ Census data for 2001} \\
\hline $\begin{array}{l}\text { Total } \\
\text { population }\end{array}$ & $7,812,159$ & $(84.2)$ & 218,508 & (2.4) & 232,507 & $(2.5)$ & 99,713 & $(1.1)$ & 136,170 & $(1.5)$ & 106,616 & $(1.1)$ & 36,523 & $(0.4)$ & 635,618 & (6.9) \\
\hline \multicolumn{17}{|l|}{ Sex } \\
\hline Male & $4,005,190$ & (51.3) & 111,778 & $(51.2)$ & 118,661 & $(51.0)$ & 50,691 & $(50.8)$ & 68,602 & $(50.4)$ & 53,423 & $(50.1)$ & 18,507 & (50.7) & 324,055 & (51.0) \\
\hline Female & $3,806,969$ & $(48.7)$ & 106,730 & $(48.8)$ & 113,846 & $(49.0)$ & 49,022 & $(49.2)$ & 67,568 & $(49.6)$ & 53,193 & $(49.9)$ & 18,016 & $(49.3)$ & 311,563 & $(49.0)$ \\
\hline \multicolumn{17}{|l|}{ Age } \\
\hline $0-4$ & $2,416,850$ & (30.9) & 67,805 & $(31.0)$ & 83,949 & $(36.1)$ & 36,154 & (36.3) & 50,484 & $(37.1)$ & 32,135 & $(30.1)$ & 10,356 & $(28.4)$ & 228,505 & (36.0) \\
\hline $5-9$ & $2,638,626$ & (33.8) & 71,642 & (32.8) & 76,931 & (33.1) & 32,206 & (32.3) & 46,081 & (33.8) & 35,661 & (33.4) & 11,345 & (31.1) & 210,037 & (33.0) \\
\hline $10-14$ & $2,756,683$ & (35.3) & 79,061 & $(36.2)$ & 71,627 & (30.8) & 31,353 & (31.4) & 39,605 & (29.1) & 38,820 & (36.4) & 14,822 & (40.6) & 197,076 & (31.0) \\
\hline \multicolumn{17}{|l|}{ Deprivation } \\
\hline Low & $1,557,414$ & (19.9) & 81,580 & (37.3) & 158,961 & (68.4) & 75,330 & (75.5) & 87,592 & $(64.3)$ & 60,267 & (56.5) & 9023 & $(24.7)$ & 221,578 & (34.9) \\
\hline Middle & $4,622,489$ & (59.2) & 113,946 & (52.1) & 66,152 & (28.5) & 22,574 & (22.6) & 44,348 & (32.6) & 43,320 & (40.6) & 20,051 & (54.9) & 314,577 & (49.5) \\
\hline High & $1,632,256$ & (20.9) & 22,982 & (10.5) & 7394 & (3.2) & 1809 & (1.8) & 4230 & (3.1) & 3029 & (2.8) & 7449 & (20.4) & 99,463 & (15.6) \\
\hline $\begin{array}{l}\text { Country of birth: } \\
\text { UK }\end{array}$ & * & * & 202,371 & (92.6) & 211,770 & (91.1) & 88,068 & (88.3) & 92,266 & (67.8) & 99,095 & (92.9) & 28,963 & (79.3) & & . \\
\hline Other & * & * & 16,137 & (7.4) & 20,737 & (8.9) & 11,645 & (11.7) & 43,904 & (32.2) & 7521 & (7.1) & 7560 & (20.7) & & . \\
\hline
\end{tabular}


Table 2 Number of cases and distribution of cancers across ethnic groups

\begin{tabular}{|c|c|c|c|c|c|c|c|c|c|c|c|}
\hline & \multirow{2}{*}{$\begin{array}{l}\text { White } \\
\text { N }\end{array}$} & \multirow{2}{*}{$\begin{array}{l}\text { Indian } \\
\text { N }\end{array}$} & \multirow{2}{*}{$\begin{array}{l}\text { Pakistani } \\
\text { N }\end{array}$} & \multirow{2}{*}{$\begin{array}{l}\text { Bangladeshi } \\
\text { N }\end{array}$} & \multirow{2}{*}{$\begin{array}{l}\text { Black } \\
\text { African } \\
N\end{array}$} & \multirow{2}{*}{$\begin{array}{l}\text { Black } \\
\text { Caribbean } \\
N\end{array}$} & \multirow{2}{*}{$\begin{array}{l}\text { Chinese } \\
N\end{array}$} & \multirow{2}{*}{$\begin{array}{l}\text { All other } \\
\text { ethnicities } \\
N\end{array}$} & \multicolumn{2}{|c|}{$\begin{array}{l}\text { No ethnicity } \\
\text { recorded }\end{array}$} & \multirow{2}{*}{$\begin{array}{l}\text { Total } \\
\text { N }\end{array}$} \\
\hline & & & & & & & & & N & $(\%)$ & \\
\hline Leukaemias & 2329 & 72 & 115 & 34 & 35 & 28 & 10 & 376 & 224 & (7.0) & 3223 \\
\hline $\begin{array}{l}\text { Lymphomas \& reticuloendothelial } \\
\text { neoplasms }\end{array}$ & 761 & 34 & 33 & 13 & 37 & 4 & 2 & 138 & 137 & (11.8) & 1159 \\
\hline $\begin{array}{l}\text { CNS \& intracranial \& intraspinal } \\
\text { neoplasms }\end{array}$ & 1694 & 46 & 38 & 7 & 36 & 30 & 3 & 255 & 234 & $(10.0)$ & 2343 \\
\hline Other solid tumors & 2739 & 49 & 91 & 26 & 84 & 37 & 25 & 425 & 459 & $(11.7)$ & 3935 \\
\hline All cancers & 7523 & 201 & 277 & 80 & 192 & 99 & 40 & 1194 & 1054 & (9.9) & 10,660 \\
\hline
\end{tabular}

\section{Comparing cancer incidence between ethnic groups}

The total number of cancers in each ethic group is presented in Table 2, and analyses comparing the relative frequency (rates) of these cancers by ethnic group are presented graphically (see Figures).

Leukaemias, then CNS cancers were the commonest in most ethnic groups except in Black Africans who had a similar absolute number of leukaemias, lymphomas and CNS cancers.

All analyses (Figures) are relative to Whites as the baseline group.

For all cancers (Fig. 1), there was little difference in risk between South Asians and Whites. However, there was strong evidence of heterogeneity within the group with

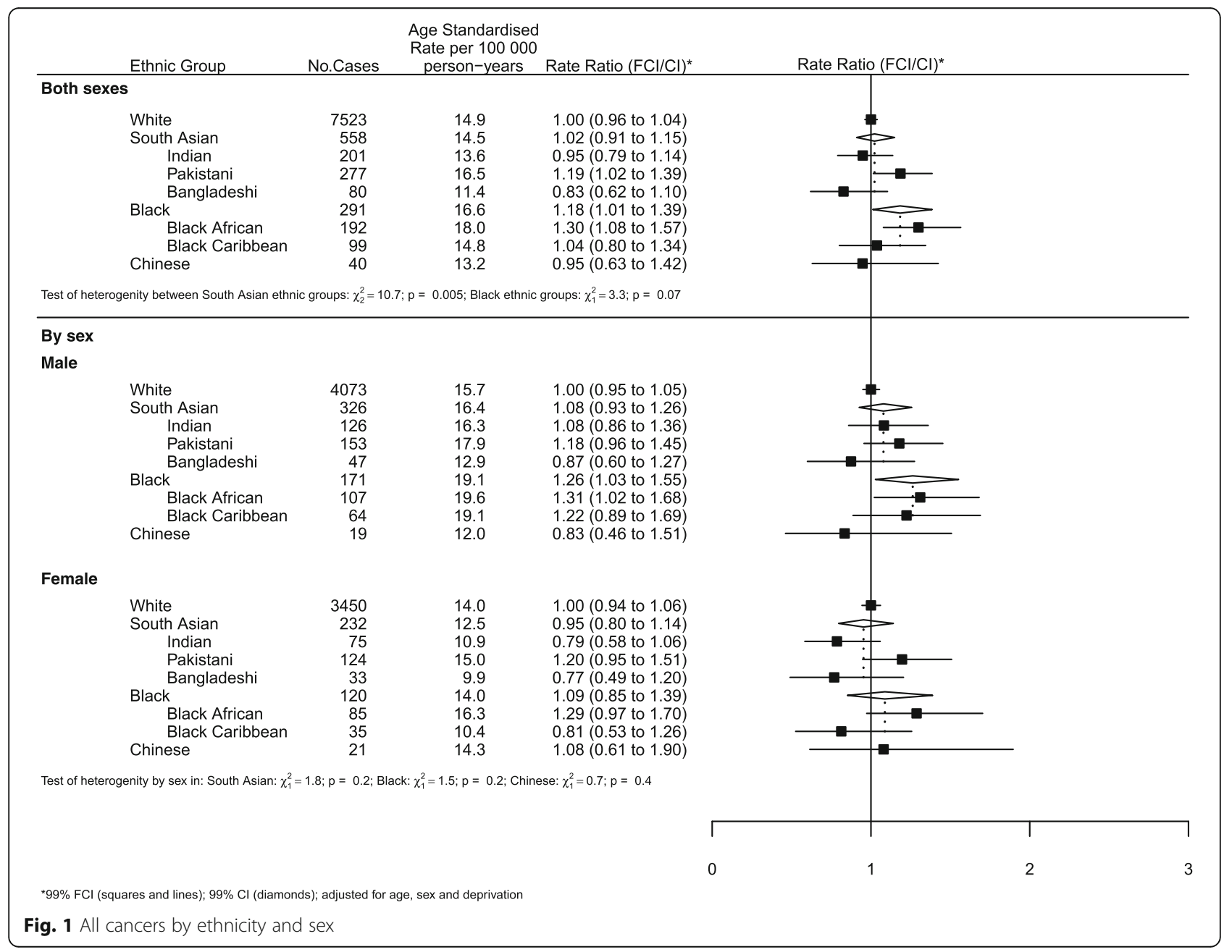


Pakistanis at greater risk than Indians or Bangladeshis (RRs of $1.19,0.95$ and 0.83 respectively, $p=0.005$ ). Risks among Blacks were higher than those of Whites, with no difference observed between Black Africans and Black Caribbeans.

For leukaemias (Fig. 2), the risk among South Asians was approximately $30 \%$ higher than that of Whites. Again, there was evidence of heterogeneity within this group with Pakistanis at greater risk than Indians or Bangladeshis (RRs of 1.58, 1.20 and 1.13 respectively, $p=0.03$ ).

For lymphomas and reticulendothelial neoplasms (Fig. 3), both South Asians and Blacks were at increased risk. The risk for South Asians was approximately 50\% higher than Whites and there was little evidence of heterogeneity within this group. The risk for Blacks was approximately $75 \%$ higher than Whites; there was insufficient information to examine heterogeneity within this group. Subgroup analysis revealed evidence of heterogeneity by sex in South Asians; the relative risk for males was higher than for females (RRs of 1.79 and 0.94 respectively, $p=0.03$ ).
For CNS neoplasms (Fig. 4), the risk for South Asians was 25\% lower than that of Whites. There was strong evidence of heterogeneity within the group with Pakistanis at lower risk than Indians (0.68 and 0.95 respectively; $p=0.005$ ).

For other cancers (Fig. 5), while the risk for South Asians was similar to Whites, there was evidence of heterogeneity within this group. Indians and Bangladeshis were at lower risk than Pakistanis ( $R$ Rs $=0.64,0.76$ and 1.09 respectively; $p=0.007$ ). The risk for Blacks was approximately $40 \%$ higher than Whites. There was some evidence of heterogeneity within this group with Black Africans at higher risk than Black Caribbeans (1.59 and 1.09 respectively; $p=0.05$ ).

\section{Missing data and sensitivity analysis}

For childhood cancers registered in the period 2001-2007, ethnicity from HES was $88 \%$ complete and from Cancer Registries it was 53\% complete. The percentage of missing ethnicity data from HES that was supplemented by Cancer

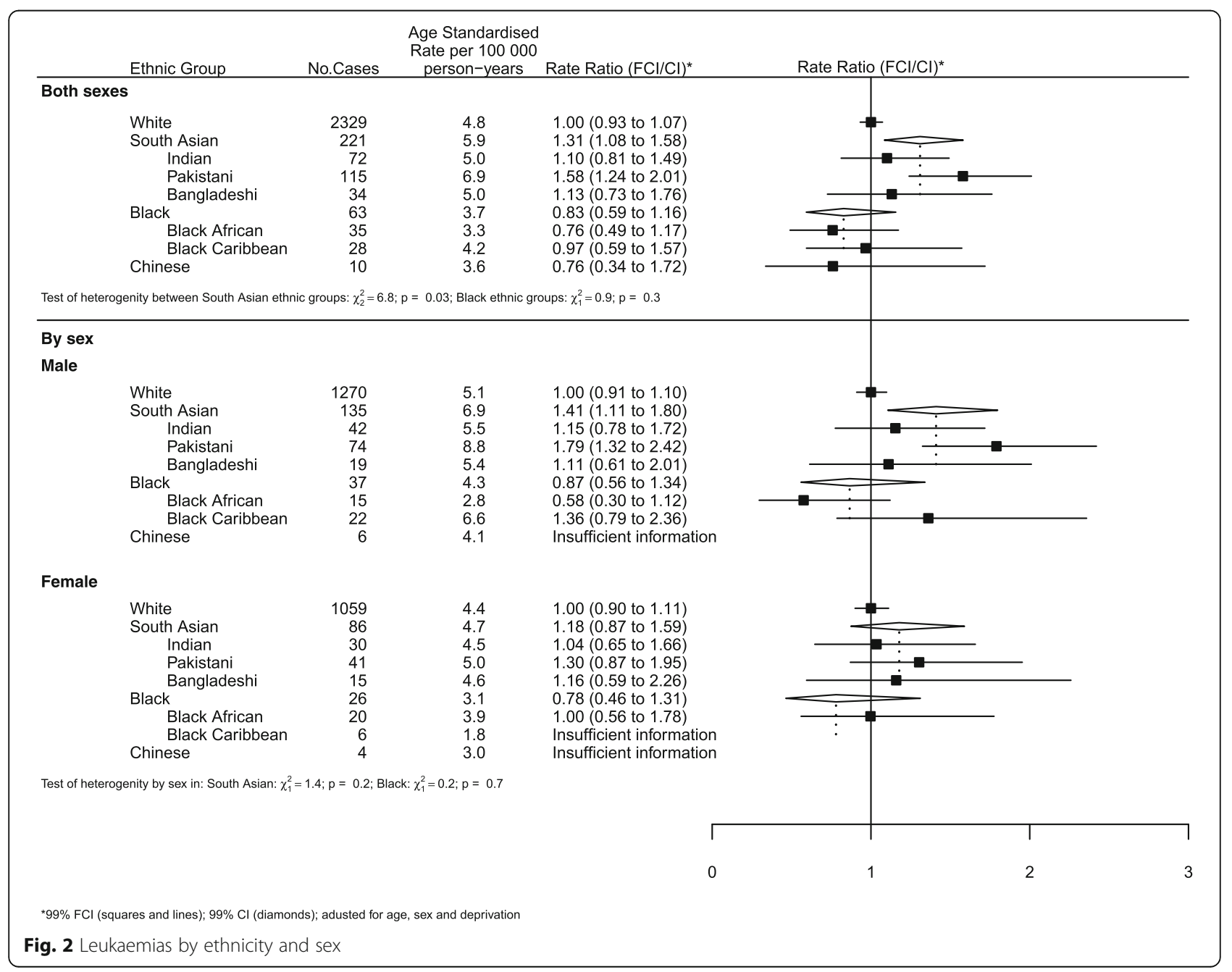




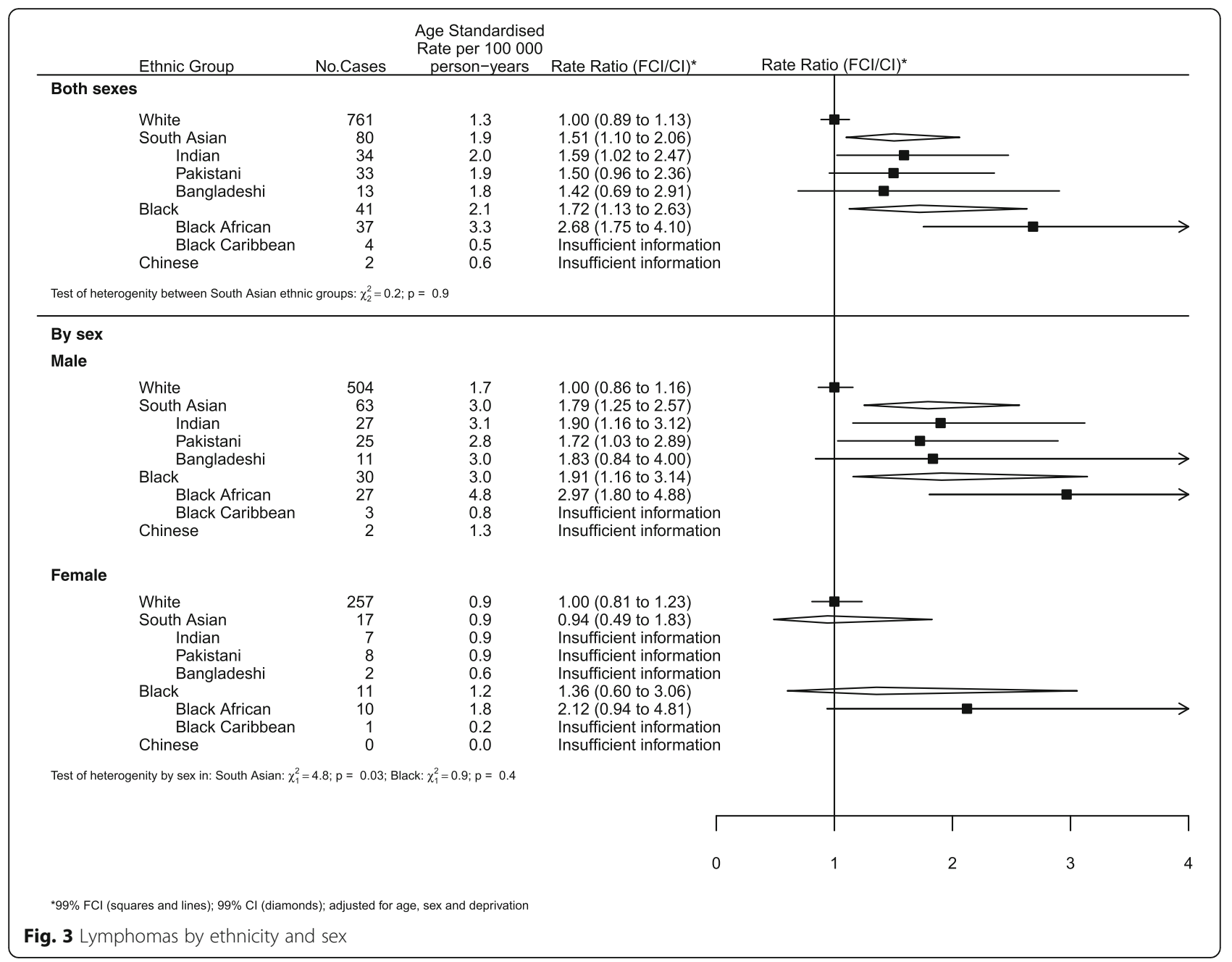

Registry data was 3\%. Our missing ethnicity data as a whole ranged (for each cancer) from $7.0 \%-11.8 \%$ (Table 2).

The incidence rate ratios for each (and all) cancer (Additional file 1: Figure S1) were very similar after sensitivity analyses (using multiple imputations of the missing ethnicity values based on age, sex, income and site of cancer).

\section{Discussion}

Analysing nationwide data for childhood cancer, we have presented results in this paper that suggest an overall increased risk of childhood cancers in Pakistani and Black African children relative to White children. We were also able to further assess the major childhood cancers and their incidence within self-reported ethnic groups. Here, we confirmed the well described [24-28] increased risk of leukaemia and lymphoma in South Asian children, but for leukaemia also show this being due to the greater risk in Pakistani children in particular. In contrast to our findings in Indian children in Leicester,
South Asian children appeared to have a lesser risk of CNS cancers. This has also been found in previous studies $[24,27,29,30]$, but these studies were underpowered and did not reach statistical significance, nor provide evidence for the lower risk of CNS cancers in Pakistani children compared to Indian children. Finally, an increased risk of 'other solid tumours' was observed in Black African children, likely driven by the previously described excess of renal tumours in this ethnic group $[31,32]$, though in this study we did not have sufficient numbers to estimate the relative risk.

We have previously discussed [12] how ethnicity is likely a proxy for genetic and/or environmental factors that might modify cancer risk, and how varying rates of cancers between ethnic groups may therefore be explicable through exploring the (differing) prevalence of putative risk/protective factors between ethnic groups. Where data for different ethnic groups could be found, some such factors are presented in Table 3, and discussed further below. 


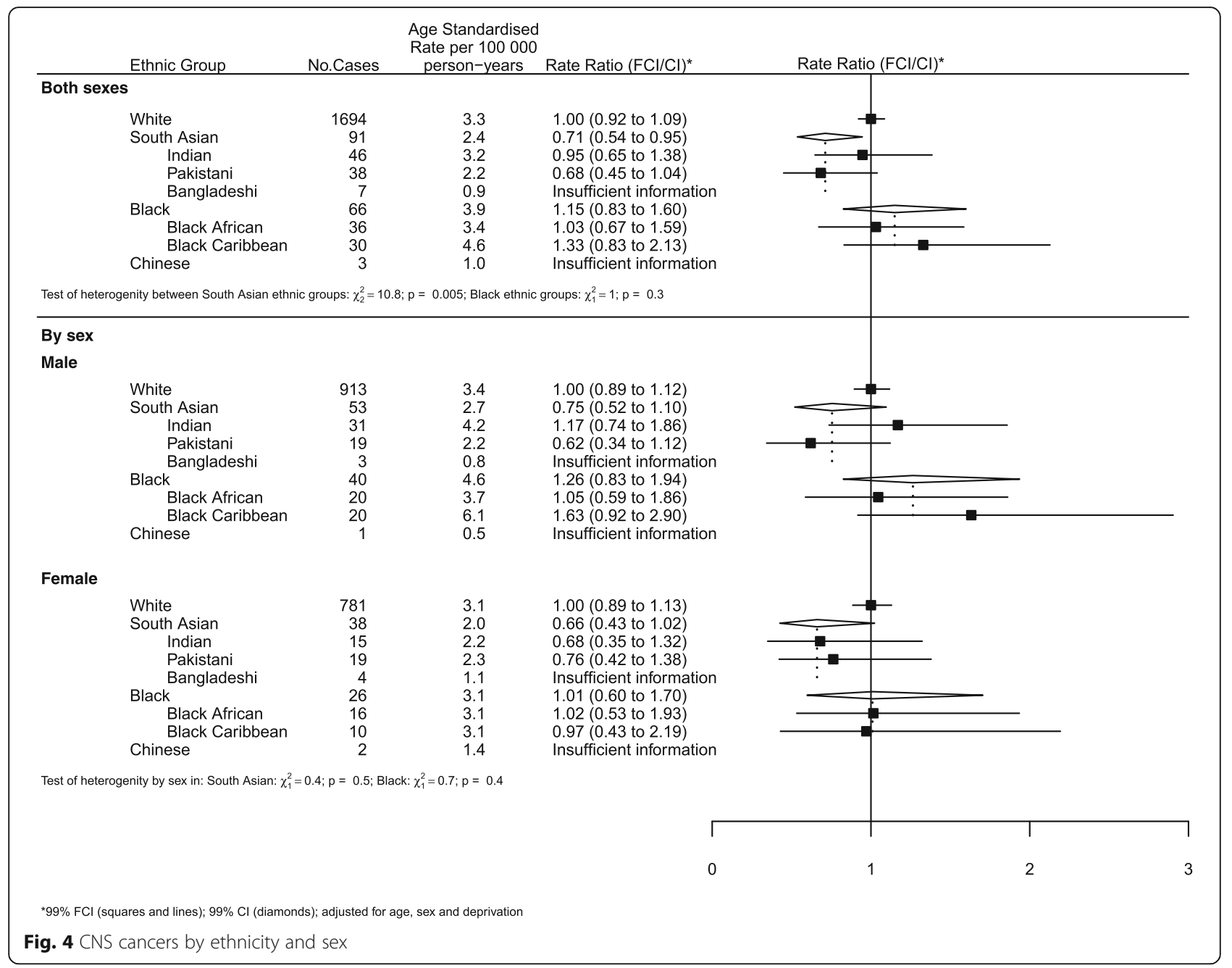

High birthweight has been associated with an increased risk of leukaemia (and possibly non-leukaemia cancers in older - $\geq 3$ years old - children) [33]. Similarly, advancing maternal age has also been associated with a small increased risk $(<10 \%)$ [34] in all groups of childhood cancer - leukaemia, lymphoma, CNS - analysed in this study. The above and other factors, such as maternal alcohol consumption in pregnancy [35], and maternal [36, 37] and paternal smoking $[38,39]$, all of which been shown to be associated with an increased childhood cancer risk (albeit inconsistently and to varying degrees for different cancers and subtypes) are all generally of greater prevalence in British Whites. Yet, our main findings are those of an increased cancer risk overall, and in leukaemias and lymphomas in particular, in some South Asian and the Black African ethnic minority groups.

As seen in Table 1, whilst a greater proportion of these groups in whom we observed a higher risk of leukaemias (Pakistanis) and lymphomas (South Asians and Black Africans) are from a lower income domain (and this study has adjusted for deprivation), recent large representative population based studies have not observed an association of deprivation with leukaemia or lymphoma subtypes [40, 41].

The relatively greater prevalence of HIV in Black Africans (in whom HIV exposure is mainly through sex between men and women [42]) is likely driving the increased risk of childhood lymphoma observed here and in other studies [43-45].

The one group of cancers in which a reduced risk relative to British Whites was observed $(R R=0.71)$ was in CNS cancers in South Asian children (apparently driven by a $32 \%$ lesser risk in Pakistani children). This finding is in keeping with previous UK studies (referenced above), many of which were in communities wherein there are large Pakistani populations, and showed a similar (though non-significant) reduced risk in South Asians relative to non-South Asians.

There are few well established risk factors for childhood CNS cancers [46-48]. Of these are a number of 


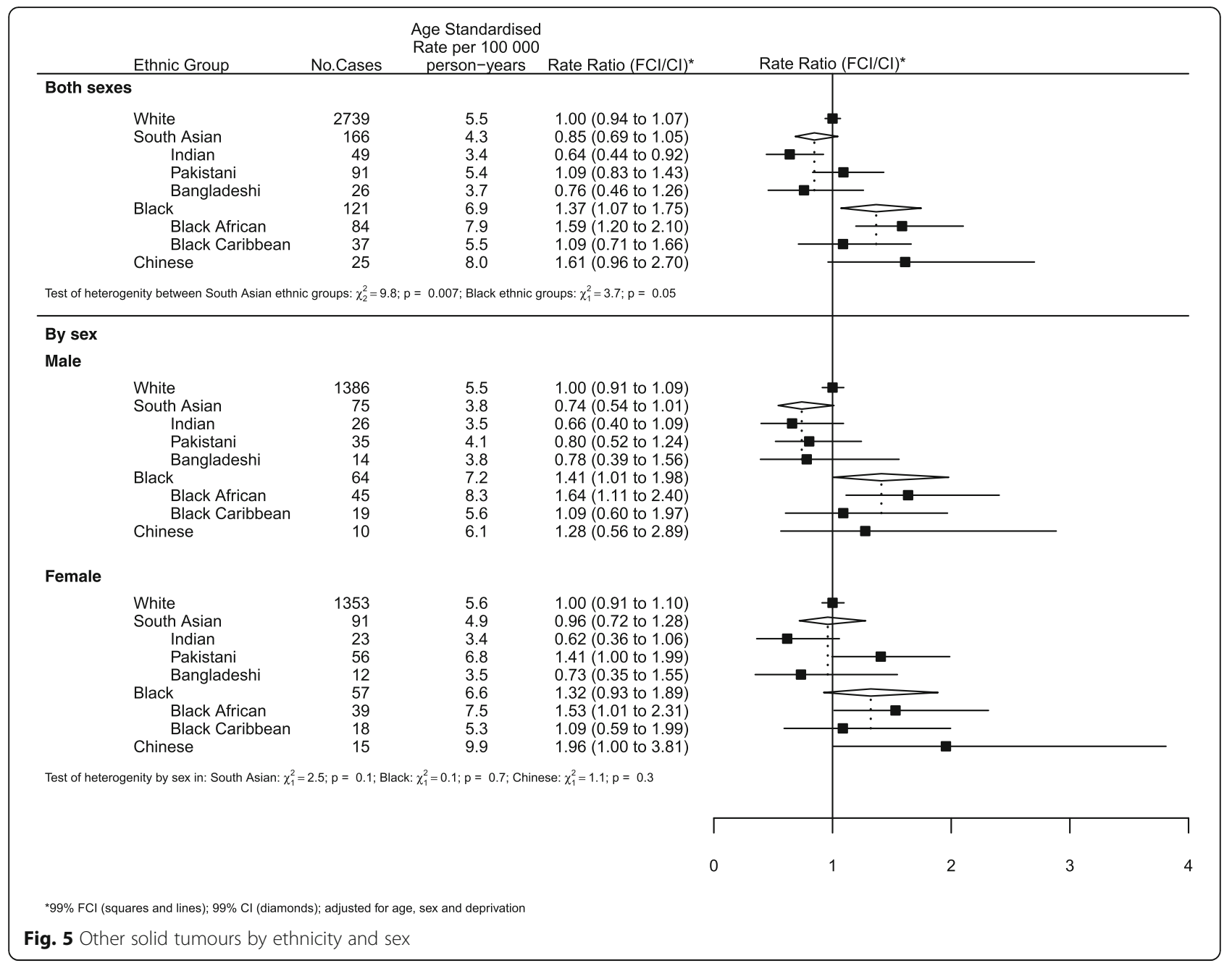

hereditary syndromes, which given the higher rate of consanguineous marriage in Pakistani families [49], one might expect a similarly increased risk of CNS cancers. However, such syndromes are thought likely to contribute to relatively few cases [50]. Asthma, or atopy more generally, is a more prevalent, proposed protective factor in CNS cancers [51, 52]. However, its prevalence does not appear to be markedly different across different ethnic groups [53] (Table 3).

This study has many of the strengths of our previous studies, namely the use of self-assigned ethnicity as a more accurate measure of ethnicity, as well as the same method being used for both numerator (Cancer Registry and HES) and denominator (Census), and the ability to separate large heterogeneous ethnic groupings (e.g. South Asian, Black) into more ethnically similar subgroups.

A further additional strength of this study relative to our analysis of childhood cancer in Indian and White children in Leicester was the use of national data, with this much greater sample size and number of outcomes allowing for greater power and precision in our estimates. We were able to adjust for age, sex and deprivation (all potential confounders in studying the association between ethnicity and cancers), and indeed also present results by sex. Using national data, where the method of ascertainment of cases is similar across the country also allows for a more accurate comparison between ethnic groups relative to those studies which compare rates of disease in groups in different countries. This is, to our knowledge, the first national study of childhood cancer incidence rate ratios between ethnic groups using self-assigned ethnicity. Additionally, there was little missing ethnicity data (Table 2) in these cancers, markedly lower than in our previous studies and other studies which have used HES data in combination with other methods [30].

Limitations remain however, in this being a population level study without information on individual exposures. Further, despite our presenting results by smaller, more homogenous ethnic subgroups, there remain within 
Table 3 Prevalence of some risk factors associated with childhood cancers, by ethnic group in the general population (most data sources: 2001-2010)

\begin{tabular}{|c|c|c|c|c|c|c|c|c|}
\hline & $\begin{array}{l}\text { Cancer Associated } \\
\text { with Risk Factor }^{\mathrm{a}}\end{array}$ & $\begin{array}{l}\text { British } \\
\text { White }\end{array}$ & $\begin{array}{l}\text { British } \\
\text { Indian }\end{array}$ & $\begin{array}{l}\text { British } \\
\text { Pakistani }\end{array}$ & $\begin{array}{l}\text { British } \\
\text { Bangladeshi }\end{array}$ & $\begin{array}{l}\text { British Black } \\
\text { African }\end{array}$ & $\begin{array}{l}\text { British Black } \\
\text { Caribbean }\end{array}$ & $\begin{array}{l}\text { British } \\
\text { Chinese }\end{array}$ \\
\hline \multicolumn{9}{|l|}{ Parental risk factors: } \\
\hline $\begin{array}{l}\text { Maternal age at pregnancy } \\
>35 \text { years }(\%)[34,56,57]\end{array}$ & $\begin{array}{l}\text { Leukaemia; Lymphoma; } \\
\text { CNS; Bone; Wilm's }\end{array}$ & 20 & 12 & 10 & 7 & 20 & 26 & - \\
\hline $\begin{array}{l}\text { Maternal alcohol intake in } \\
\text { pregnancy }(\%)[35,56,58]\end{array}$ & Acute Myeloid Leukaemia & 37 & 12 & 0 & 0 & 20 & 20 & - \\
\hline $\begin{array}{l}\text { Maternal smoking in } \\
\text { pregnancy }(\%)[36,37,56,58]\end{array}$ & Acute Myeloid Leukaemia; CNS & 37 & 6 & 4 & 4 & 22 & 22 & - \\
\hline $\begin{array}{l}\text { Epstein-Barr virus prevalence } \\
\text { in pregnancy }(\%)^{\mathrm{b}}[59]\end{array}$ & Hodgkin's Disease & 94 & 94 & 94 & 94 & - & - & - \\
\hline $\begin{array}{l}\text { Breastfed for at least four } \\
\text { months (\%) }[58,60,61]\end{array}$ & $\downarrow$ Acute Lymphoblastic Leukaemia & 27 & 41 & 26 & 26 & 50 & 50 & - \\
\hline $\begin{array}{l}\text { Paternal smoking (male } \\
\text { prevalence 2003/4) } \\
{[38,39,56,62]}\end{array}$ & Acute Lymphoblastic Leukaemia & 27 & 23 & 18 & 35 & 26 & 22 & 19 \\
\hline \multicolumn{9}{|l|}{ General Risk Factors: } \\
\hline $\begin{array}{l}\text { Household size (mean) } \\
{[63,64]}\end{array}$ & Leukaemia & 2.3 & 3.4 & 4.3 & 4.3 & 2.6 & 2.2 & - \\
\hline $\begin{array}{l}\text { High birth weight } \\
>4000 \mathrm{~g}(\%)[33,56,57]\end{array}$ & All childhood cancers & 13 & 3 & 5 & 3 & 9 & 6 & - \\
\hline HIV $(\%)^{\mathrm{b} c}[43,65]$ & Non-Hodgkin's lymphoma & 53 & 1 & 1 & 1 & 35 & 3 & - \\
\hline $\begin{array}{l}\text { Epstein-Barr virus } \\
\text { prevalence }(\%)^{b d} \text { [66] }\end{array}$ & Hodgkin's disease & 44 & 95 & 95 & 95 & - & - & - \\
\hline $\begin{array}{l}\text { Asthma prevalence (\%) } \\
{[52,53]}\end{array}$ & $\downarrow C N S$ & 32 & 24 & 29 & 26 & 23 & 33 & - \\
\hline
\end{tabular}

airection of effect increased unless indicated with $\downarrow$

${ }^{b}$ Combined estimate (italicised) for some ethnic minority groups

'Proportional breakdown across ethnicities of diagnosed HIV infected adults seen for care in England, Wales and NI (2003)

'within a study of children with Hodgkin's disease, diagnosed 1981-1999

- Data not available

these groups a degree of heterogeneity, e.g. with Black Africans having a number of countries of origin, and similarly with Indians and Pakistanis originating from a number of provinces and states, with the cultural and genetic diversity that results in different ethnic groups.

As we have previously noted [6], we considered the 'White' classification to be 'British White' - though there would have been 'Irish White' and 'Other White' present in the 'White' classification (until 2003). However, these would have been very few (4\% in the 2001 census), and unlikely therefore to have affected the results for British Whites. Finally, despite our use of self-assigned ethnicity as the current best measure of ethnicity, there remains a discordance - more so in ethnic minorities - between HES ethnicity recording and self-assigned ethnicity and there is an ongoing need to improve the accuracy of this data [54].

\section{Conclusions}

Improvements in data collection and linkage of databases in recent years have permitted a more detailed and accurate study of ethnicity as a possible risk or protective factor in a number of different diseases. Initial descriptive studies such as this highlight associations between ethnicity as an exposure and outcomes such as childhood cancers; whilst it is not yet of course possible to draw conclusions regarding correlation, the awareness of these differences between ethnic groups based on high quality data allows for better public health planning and targeted initiatives, and the development of further research to aim to understand why these differences might exist, potentially giving rise to individual level, translational research [55].

\section{Additional file}

Additional file 1: Figure S1. Sensitivity Analysis - Each cancer and all cancers by ethnicity, using imputed data. Sensitivity analyses for each cancer, and all cancers, by ethnicity (using multiple imputations of the missing ethnicity values based on age, sex, income and site of cancer). (PDF 3 kb)

\section{Abbreviations}

(F)Cl: (floating) confidence intervals; (I)RR: (incidence) rate ratios; ASR: Agestandardised rates; CNS: Central nervous system; CRUK: Cancer Research UK; 
HES: Hospital episodes statistics; HIV: Human immunodeficiency virus; ICCC3: International classification of childhood cancer, 3rd edition; ICD10: International classification of diseases, 10th revision; ICD-O-2/ 3: International classification of diseases of oncology, 2nd/3rd revisions; IMD 2007: Index of multiple deprivation 2007; NCIN: National cancer intelligence network; ONS: Office of National Statistics

\section{Acknowledgements}

We would like to thank the National Cancer Intelligence Network and the Office of National Statistics for providing the data, and Cancer Research UK and the University of Oxford's Cancer Epidemiology Unit for their support and funding.

\section{Funding}

RA and IB are employees of, and SS an honorary research fellow at, the University of Oxford's Cancer Epidemiology Unit which is supported by Cancer Research UK. The sponsor of the study had no role in design and conduct of the study; collection, management, analysis and interpretation of the data; and preparation, review or approval of the manuscript.

\section{Availability of data and materials}

The data that support the findings of this study are available from NCIN but restrictions apply to the availability of these data, which were used under license for the current study, and so are not publicly available. Data are however available from the authors upon reasonable request and with permission of $\mathrm{NCIN}$.

\section{Authors' contributions}

All authors (SS, IB and RA) participated in the design of the study, as well as drafting and approval of the final manuscript. IB drafted the Methods section, performed the statistical analyses, and created the Tables and Figures.

\section{Ethics approval and consent to participate}

This study was approved by the Oxford Research Ethics Committee (this was a requirement for the data to be released by NCIN). Consent was not obtained because the data were analysed anonymously (de-identified and aggregated).

\section{Consent for publication}

Not applicable.

\section{Competing interests}

The authors declare that they have no competing interests

\section{Publisher's Note}

Springer Nature remains neutral with regard to jurisdictional claims in published maps and institutional affiliations.

Received: 5 December 2016 Accepted: 14 August 2017 Published online: 25 August 2017

\section{References}

1. National Cancer Intelligence Network and Cancer Research UK: Cancer Incidence and Survival by Major Ethnic Group, England 2002-2006. 2009

2. Ali R, Barnes I, Cairns BJ, Finlayson AE, Bhala N, Mallath M, Beral V. Incidence of gastrointestinal cancers by ethnic group in England, 2001-2007. Gut. 2013;62(12):1692-703

3. Shirley MH, Sayeed S, Barnes I, Finlayson A, Ali R. Incidence of haematological malignancies by ethnic group in England, 2001-7. British journal of haematology. 2013;163(4):465-77.

4. Finlayson A, Barnes I, Sayeed S, Mclver B, Beral V, Ali R. Incidence of thyroid cancer in England by ethnic group, 2001-2007. Br J Cancer. 2014;110(5):1322-7.

5. Shirley MH, Barnes I, Sayeed S, Finlayson A, Ali R. Incidence of breast and gynaecological cancers by ethnic group in England, 2001-2007: a descriptive study. BMC Cancer. 2014;14:979.

6. Maruthappu M, Barnes I, Sayeed S, Ali R. Incidence of prostate and urological cancers in England by ethnic group, 2001-2007: a descriptive study. BMC Cancer. 2015;15:753.

7. Maile EJ, Barnes I, Finlayson AE, Sayeed S, Ali R. Nervous system and intracranial tumour incidence by ethnicity in England, 2001-2007: a descriptive epidemiological study. PLoS One. 2016;11(5):e0154347.
8. Parkin DM, Khlat M. Studies of cancer in migrants: rationale and methodology. Eur J Cancer. 1996;32A(5):761-71.

9. Office for National Statistics: Ethnic group statistics : a guide for the collection and classification of ethnicity data. 2003.

10. Mathur R, Grundy E, Smeeth L: Availability and use of UK based ethnicity data for health research. 2013

11. Office for National Statistics: Death registration summary tables - England and Wales, 2011 (Final). 2012.

12. Sayeed S, Barnes I, Cairns BJ, Finlayson A, Ali R. Childhood cancer incidence in British Indians \& Whites in Leicester, 1996-2008. PLoS One. 2013;8(4):e61881.

13. World Health Organisation. International Statistical Classification of Diseases and Related Health Outcomes, 10th Revision. Geneva: World Health Organization; 1992.

14. World Health Organisation. International Classification of Diseases for Oncology, 3rd Revision. Geneva: World Health Organization; 2000.

15. World Health Organisation. International Classification for Diseases of Oncology, 2nd Revision. Geneva: World Health Organization; 1990.

16. Noble M, mcLennan D, Wilkinson K, Whitworth A, Barnes H, Dibben C. The English Indices of Deprivation 2007. London: Communities and Local Government; 2008.

17. Steliarova-Foucher E, Stiller C, Lacour B, Kaatsch P. International classification of childhood cancer, third edition. Am Cancer Soc. 2005;103(7):1457-67.

18. van Laar M, McKinney PA, Parslow RC, Glaser A, Kinsey SE, et al. Cancer incidence among the south Asian and non-south Asian population under 30 years of age in Yorkshire, UK. Br J Cancer. 2010;108:1448-52.

19. Segi M. Cancer Mortality for Selected Sites in 24 Countries (1950-57). Sendai: Tohoku University School of Public Health; 1960.

20. Plummer M. Improved estimates of floating absolute risk. Stat Med. 2004; 23(1):93-104.

21. Easton DF, Peto J, Babiker AGAG. Floating absolute risk - an alternative to relative risk in survival and case-control analysis avoiding an arbitrary reference group. Stat Med. 1991:10(7):1025-35.

22. StataCorp. Stata statistical software: release 13. College Station: StataCorp LP; 2013.

23. R Core Team. R: a language and enviroment for statistical computing. Vienna: R Foundation for Statistical Computing; 2014

24. Stiller CA, McKinney PA, Bunch KJ, Bailey CC, Lewis IJ. Childhood cancer and ethnic group in Britain: a United Kingdom children's Cancer Study Group (UKCCSG) study. Br J Cancer. 1991:64(3):543-8.

25. Muir KR, Parkes SE, Mann JR, Stevens MC, Cameron AH. Childhood cancer in the West Midlands: incidence and survival, 1980-1984, in a multi-ethnic population. Clin Oncol (R Coll Radiol). 1992;4(3):177-82.

26. Cummins C, Winter H, Maric R, Cheng KK, Silcocks P, Varghese C, Batlle G. Childhood cancer in the south Asian population of England (1990-1992). Br J Cancer. 2001:84(9):1215-8.

27. McKinney PA, Feltbower RG, Parslow RC, Lewis IJ, Glaser AW, Kinsey SE. Patterns of childhood cancer by ethnic group in Bradford, UK 1974-1997. Eur J Cancer. 2003;39(1):92-7.

28. Winter H, Cheng KK, Cummins C, Maric R, Silcocks P, Varghese C. Cancer incidence in the south Asian population of England (1990-92). Br J Cancer. 1999;79(3-4):645-54.

29. Powell JE, Parkes SE, Cameron AH, Mann JR. Is the risk of cancer increased in Asians living in the UK? Arch Dis Child. 1994;71(5):398-403.

30. van Laar M, McKinney PA, Parslow RC, Glaser A, Kinsey SE, Lewis IJ, Picton SV, Richards M, Shenton G, Stark D, et al. Cancer incidence among the south Asian and non-south Asian population under 30 years of age in Yorkshire, UK. Br J Cancer. 2010;103(9):1448-52.

31. Breslow N, Olshan A, Beckwith JB, Moksness J, Feigl P, Green D. Ethnic variation in the incidence, diagnosis, prognosis, and follow-up of children with Wilms' tumor. J Natl Cancer Inst. 1994:86(1):49-51.

32. Axt J, Murphy AJ, Seeley EH, Martin CA, Taylor C, Pierce J, Caprioli RM, Whiteside M, Lovvorn HN 3rd. Race disparities in Wilms tumor incidence and biology. J Surg Res. 2011;170(1):112-9.

33. Paltiel $\mathrm{O}$, Tikellis $\mathrm{G}$, Linet $\mathrm{M}$, Golding J, Lemeshow S, Phillips G, Lamb K, Stoltenberg C, Haberg SE, Strom M, et al. Birthweight and childhood cancer: preliminary findings from the international childhood cancer cohort consortium (I4C). Paediatr Perinat Epidemiol. 2015:29(4):335-45.

34. Johnson KJ, Carozza SE, Chow EJ, Fox EE, Horel S, McLaughlin CC, Mueller BA, Puumala SE, Reynolds P, Von Behren J, et al. Parental age and risk of childhood cancer: a pooled analysis. Epidemiology. 2009;20(4):475-83.

35. Latino-Martel P, Chan DS, Druesne-Pecollo N, Barrandon E, Hercberg S, Norat T. Maternal alcohol consumption during pregnancy and risk of 
childhood leukemia: systematic review and meta-analysis. Cancer Epidemiol Biomark Prev. 2010;19(5):1238-60

36. Brooks DR, Mucci LA, Hatch EE, Cnattingius S. Maternal smoking during pregnancy and risk of brain tumors in the offspring. A prospective study of 1.4 million Swedish births. Cancer Causes Control. 2004;15(10):997-1005.

37. Mucci LA, Granath F, Cnattingius S. Maternal smoking and childhood leukemia and lymphoma risk among 1,440,542 Swedish children. Cancer Epidemiol Biomark Prev. 2004;13(9):1528-33.

38. Milne E, Greenop KR, Scott RJ, Bailey HD, Attia J, Dalla-Pozza L, de Klerk NH, Armstrong BK. Parental prenatal smoking and risk of childhood acute lymphoblastic leukemia. American journal of epidemiology. 2011;175(1):4353.

39. Liu R, Zhang L, McHale CM, Hammond SK. Paternal smoking and risk of childhood acute lymphoblastic leukemia: systematic review and metaanalysis. J Oncol. 2011;2011:854584.

40. Smith A, Howell D, Patmore R, Jack A, Roman E. Incidence of haematological malignancy by sub-type: a report from the Haematological Malignancy Research Network. Br J Cancer. 2011;105(11):1684-92.

41. Adam M, Kuehni CE, Spoerri A, Schmidlin K, Gumy-Pause F, Brazzola P, Probst-Hensch N, Zwahlen M. Socioeconomic status and childhood leukemia incidence in Switzerland. Front Oncol. 2015;5:139.

42. Public Health England. National HIV surveillance data tables - Table 18: Persons seen for HIV care in the UK by ethnicity and route of exposure: 2014

43. Biggar RJ, Frisch M, Goedert JJ. Risk of cancer in children with AIDS AIDS-Cancer Match Registry Study Group. JAMA. 2000;284(2):205-9.

44. Evans JA, Gibb DM, Holland FJ, Tookey PA, Pritchard J, Ades AE. Malignancies in UK children with HIV infection acquired from mother to child transmission. Arch Dis Child. 1997;76(4):330-3.

45. Beral V, Peterman T, Berkelman R, Jaffe H. AIDS-associated non-Hodgkin lymphoma. Lancet. 1991;337(8745):805-9.

46. Schuz J, Kaletsch U, Kaatsch P, Meinert R, Michaelis J. Risk factors for pediatric tumors of the central nervous system: results from a German population-based case-control study. Med Pediatr Oncol. 2001;36(2):274-82.

47. Frei P, Poulsen AH, Johansen C, Olsen JH, Steding-Jessen M, Schuz J. Use of mobile phones and risk of brain tumours: update of Danish cohort study. BMJ. 2011;343:d6387.

48. Wrensch M, Minn Y, Chew T, Bondy M, Berger MS. Epidemiology of primary brain tumors: current concepts and review of the literature. NeuroOncology. 2002;4(4):278-99.

49. Sheridan E, Wright J, Small N, Corry PC, Oddie S, Whibley C, Petherick ES, Malik T, Pawson N, McKinney PA, et al. Risk factors for congenital anomaly in a multiethnic birth cohort: an analysis of the Born in Bradford study. Lancet. 2013;382(9901):1350-9.

50. Narod SA, Stiller C, Lenoir GM. An estimate of the heritable fraction of childhood cancer. Br J Cancer. 1991;63(6):993-9.

51. Roncarolo F, Infante-Rivard C. Asthma and risk of brain cancer in children. Cancer Causes Control. 2012;23(4):617-23.

52. Harding NJ, Birch JM, Hepworth SJ, McKinney PA. Atopic dysfunction and risk of central nervous system tumours in children. Eur J Cancer. 2008;44(1):92-9

53. Whitrow MJ, Harding S. Asthma in Black African, Black Caribbean and South Asian adolescents in the MRC DASH study: a cross sectional analysis. BMC pediatrics. 2010;10(1):18.

54. Saunders CL, Abel GA, El Turabi A, Ahmed F, Lyratzopoulos G. Accuracy of routinely recorded ethnic group information compared with self-reported ethnicity: evidence from the English Cancer Patient Experience survey. BMJ Open. 2013;3(6).

55. Irving GR, Iwuji CO, Morgan B, Berry DP, Steward WP, Thomas A, Brown K, Howells LM. Combining curcumin (C3-complex, Sabinsa) with standard care FOLFOX chemotherapy in patients with inoperable colorectal cancer (CUFOX): study protocol for a randomised control trial. Trials. 2015;16(1):1-10.

56. Linet MS, Wacholder S, Zahm SH. Interpreting epidemiologic research: lessons from studies of childhood cancer. Pediatrics. 2003;112(Supplement 1):218-32.

57. Moser K, Stanfield KM, Leon DA. Birthweight and gestational age by ethnic group, England and Wales 2005: introducing new data on births. Health Stat Q. 2008(39):22-31, 34-55.

58. Hawkins SS, Lamb K, Cole TJ, Law C. Influence of moving to the UK on maternal health behaviours: prospective cohort study. BMJ. 2008; 336(7652):1052-5.
59. Pembrey L, Raynor P, Griffiths P, Chaytor S, Wright J, Hall AJ. Seroprevalence of cytomegalovirus, Epstein Barr virus and varicella zoster virus among pregnant women in Bradford: a cohort study. PLoS One. 2013;8(11):e81881.

60. Infante-Rivard C, Fortier I, Olson E. Markers of infection, breast-feeding and childhood acute lymphoblastic leukaemia. Br J Cancer. 2000;83(11):1559-64.

61. Rudant J, Orsi L, Menegaux F, Petit A, Baruchel A, Bertrand Y, Lambilliotte A, Robert A, Michel G, Margueritte G, et al. Childhood acute leukemia, early common infections, and allergy: the ESCALE study. Am J Epidemiol. 2010; 172(9):1015-27.

62. Karlsen S, Millward D, Sandford A. Investigating ethnic differences in current cigarette smoking over time using the health surveys for England. The European Journal of Public Health. 2011;22(2):254-6.

63. Bevier $M$, Weires $M$, Thomsen $H$, Sundquist J, Hemminki K. Influence of family size and birth order on risk of cancer: a population-based study. BMC Cancer. 2011:11:163.

64. National Statistics: Average household size by ethnic group of household reference person, Great Britain 2001 and 2002 combined. 2004.

65. Rice BD, Payne LJ, Sinka K, Patel B, Evans BG, Delpech V. The changing epidemiology of prevalent diagnosed HIV infections in England, Wales, and Northern Ireland, 1997 to 2003. Sex Transm Infect. 2005;81(3):223-9.

66. Flavell KJ, Biddulph JP, Powell JE, Parkes SE, Redfern D, Weinreb M, Nelson $P$, Mann JR, Young LS, Murray PG. South Asian ethnicity and material deprivation increase the risk of Epstein-Barr virus infection in childhood Hodgkin's disease. Br J Cancer. 2001;85(3):350-6.

\section{Submit your next manuscript to BioMed Central and we will help you at every step:}

- We accept pre-submission inquiries

- Our selector tool helps you to find the most relevant journal

- We provide round the clock customer support

- Convenient online submission

- Thorough peer review

- Inclusion in PubMed and all major indexing services

- Maximum visibility for your research

Submit your manuscript at www.biomedcentral.com/submit
( Biomed Central 